McCarthy argues in the appendix for bringing comparative knowledge to field work, in part because knowing something about American criminal justice allowed her to exchange information with, and not just take information from, her interlocutors. In light of this advice, it is perhaps a little surprising that Trafficking Justice did not develop further the many parallels between the attitudes and behavior of Russian and American criminal justice personnel whose portfolios include human trafficking cases.

EUGENE HUSKEY

Stetson University

\title{
An Academy at the Court of the Tsars: Greek Scholars and Jesuit Education in Early Modern Russia. By Nikolaos A. Chrissidis. Dekalb, Ill.: Northern Illinois University Press, 2016. xv, 300 pp. Appendix. Notes. Bibliography. Index. Illustrations. Photographs. \$55.00, paper.
}

doi: 10.1017/slr.2017.234

Moscow's Slavo-Greko-Latin Academy, established by the Greek hieromonks Ioannikios and Sophronios Leichoudes in 1685, has long been credited by historians for bringing Greek learning to Russia. Nikolaos Chrissidis challenges that characterization with evidence that the Greek scholars imported an education system and curriculum based on Jesuit colleges in seventeenth-century Europe. As Chrisidis puts it, "the 'Greekness' of the Academy needs rethinking” (188). Indeed, the Leichoudes brothers taught subjects using the Greek language, but the content of their courses came from Jesuit textbooks and manuals that blended Aristotelianism, Scholasticism, and humanism.

The well-written and impressively researched book breaks down generally accepted arguments about seventeenth-century education in the Orthodox East by analyzing the life and careers of the Leichoudes brothers. Common historiographical arguments on so-called "Grecophile" and "Latinophile" movements in Russian education oversimplify a more integrated relationship between Greek and Latin learning; in fact, Chrissidis argues, there were no such dichotomies in tsarist educational policies. The concept of an "Orthodox Commonwealth" with a shared Byzantine-influenced culture whitewashes inherent tensions and differences that existed between the component ethnic groups. Notably, a complex "love-hate relationship" (34) arose between Russians and Greeks after the fall of Constantinople to the Turks, with extraordinary cases of Russian suspicion of the contamination of the Orthodox faith of the Greeks, while still admiring their learning. Most importantly, Greek learning in the early modern era was actually western. With limited educational opportunities inside the Ottoman Empire, Greek scholars traveled west to study becoming "influenced by the intellectual currents of Renaissance and post-Renaissance Western Europe” (35). By the seventeenth century the Jesuit curriculum dominated higher education in Europe, and the Leichoudes brothers absorbed this program of study in their own training in Venice and Padua. Thus, the Greek hieromonks actually brought the foundations of western learning to the tsarist state. The Slavo-Greko-Latin Academy followed the Jesuit two-part curriculum of grammar, poetics, and rhetoric first, followed by philosophy and theology; pedagogical methods also followed western norms, including parsing texts, competitive exercises, disputations, composition, and oratory performance (104).

Most impressively, Chrissidis looks into the actual content of the courses taught by the Leichoudes brothers in Russia by studying the instructional materials used 
in the Moscow Academy, particularly the manuals written by the Leichoudes themselves and the Jesuit or Jesuit-influenced sources they consulted. Chrissidis is the rare scholar of Russian history with the language abilities to carry this off, adeptly analyzing unpublished and published sources in ancient and modern Greek, Latin, Church Slavonic, and Russian. His informative endnotes provide excellent additional explanation on the sources, quotes, and terminology. The result is an authoritative and original perspective on late seventeenth-century Russian education.

Two chapters delve more deeply into the instructional manuals to present the concepts taught by the Leichoudes in their rhetoric and philosophy courses, laying out the courses almost lesson by lesson, showing readers what it meant to study rhetoric and philosophy at the Academy. The rhetoric course relied on Greek manuals based on the latest Jesuit prototypes, but adding an "Orthodox guise" to adjust to the needs of Orthodox Muscovy (116). More than simply technical aspects such as elocution and disposition, the students learned to add emotion and a broader subject matter of history, custom, and myth to ensure "the captivation of the audience body, mind, and soul" (127). The natural philosophy course of study under the Leichoudes brothers was a novelty for Russia, offering "a complex understanding of the natural world" (140). In astronomy and cosmology, students considered stars, comets, celestial fluidity or solidarity, planetary spheres, and the diverse perspectives of Ptolemy, Plato, Aristotle, Copernicus, and Tycho Brahe (145). Utilizing a variety of commentaries on Aristotelian natural philosophy developed by Jesuits in the mid-seventeenth century, this course of study "paved the way for the subsequent importation of more up-to-date scientific knowledge into Russia during the Petrine period" (141).

Equally notably, Chrissidis underscores the consistent cooperation between church and state in founding and supporting the Academy, even throughout turbulent political times. The known information on its graduates demonstrates that they made vital contributions to both church and state institutions. Abruptly dismissed for personal reasons from their teaching duties at the Academy in 1694, the Leichoudes continued to serve the Russian state with translations and editing in the Typography office, as well as with creating a similar academy in Novgorod. Chrissidis never overlooks the personal weaknesses of the two brothers, even as he brings them rightfully into the limelight for consideration as instrumental precursors to the westernizing educational tendencies of the Petrine era. This important monograph comprises a valuable study on the roots of western-oriented education in Russia, and, indeed, on the intellectual development of the Orthodox East.

BARBARA SKINNER Indiana State University

Threads of Empire: Loyalty and Tsarist Authority in Bashkiria, 1552-1917. By Charles Steinwedel. Bloomington: Indiana University Press, 2016. xiv, 381 pp. Notes. Bibliography. Glossary. Index. Illustrations. Photographs. Maps. \$45.00, hard bound.

doi: 10.1017/slr.2017.235

Within today's Russian Federation, ethnic Bashkirs total less than two million, or barely thirty percent of the Autonomous Republic of Bashkortostan (Bashkiria), their ostensible homeland. Since the tenth century or so, they have identified mostly as Muslims, as have their close neighbors, the Volga Tatars, who have typically overshadowed them in the regional historiography they share. Never in their recorded 